\title{
Promoting LNG as A Marine Fuel in Norway: Reflections on the Role of Global Regulations on Local Transition Niches
}

\author{
Sofiane Laribi * and Emmanuel Guy \\ Department of Management, University of Quebec at Rimouski, Rimouski, QC G5L 3A1, Canada; \\ Emmanuel_Guy@uqar.ca \\ * Correspondence: sofiane-saad_laribi@uqar.ca
}

Received: 22 October 2020; Accepted: 12 November 2020; Published: 14 November 2020

\begin{abstract}
Contemporary societies are marked by constant tensions between the notion to improve sustainability and the reluctance to engage in uncertain changes. In any sector, the transition is a delicate and complex process that involves many actors, organizations, and institutions. Niche analysis approaches such as the multilevel perspective model (MLP) explain how such a process grows from innovation within a very restricted field to its generalized application on a global scale. Shipping is a sector particularly challenged by the transition process away from heavy fuel oil towards more environment-friendly alternatives such as liquefied natural gas (LNG) or even non-fossil alternatives. Within this industry, Norway stands as an early adopter and leader of the emerging transition. Drawing from a wide discussion of the treatment of scale in transition literature and from this national case study, we propose that the transition process can emerge not only from a local niche perspective, as widely documented in the literature, but can also be driven by changes at a much larger scale and initiated by new international regulations.
\end{abstract}

Keywords: liquefied natural gas; multi-level perspective (MLP); niche-based analysis; shipping; sustainability transition

\section{Introduction}

One of the biggest challenges of western societies arguably is the way they can manage transitions towards sustainability. We believe that this challenge cannot be met without a better comprehension of the transition process. Widely, sustainability transitions (ST) examine how broad societal and industrial transformations can lead to more sustainable modes of production and consumption. However, ST challenges are aggravated by path dependencies and lock-in situations which render the transition process more complex to analyze in practice. In this vein, ST literature proposes certain tools to analyze and understand the transition process. The multi-level perspective (MLP) elaborated by Geels [1-5] is one of the more frequently used concepts. MLP attempts to conceptualize the transition process through a convergence mechanism of the macro, meso and micro levels, as we will detail in the next section. Some criticisms have arisen against the MLP model, claiming that the model offers explanations of the sustainable transition process mainly through a temporal lens and is most or only appropriate for studies with bottom-up approaches. The MLP model has also been criticized for focusing on technology and insufficiently considering the socio-political aspects of transition [6,7].

The present paper does not aim to reject the MLP model, but attempts to explore how it can be expanded and improved through its application to a particular case study. To do so, the authors will adopt a niche-based analysis (where the niche is considered as the starting point of the transition process) but with a top-down approach. Hence, we emphasize that the niche could emerge from the 
global level and not necessarily from the local level. Our contribution also pays more attention to the spatial context where the transition takes place and to the policy environment surrounding the ST. Figure 1 offers a brief overview of the methodological steps for our study. The paper is structured as follows: In Section 2 we present the MLP model to set an analysis grid to examine the sustainability transition process. In this section, we also introduce the multi-governance level adapted to the context of the sustainability transition, and we discuss ways to better consider global dimensions in the development of transition niches through a conceptual proposition. Section 3 is dedicated to the case study of the energy transition to liquefied natural gas (LNG) as a marine fuel in Norway. Finally, Section 4 offers the main conclusions.

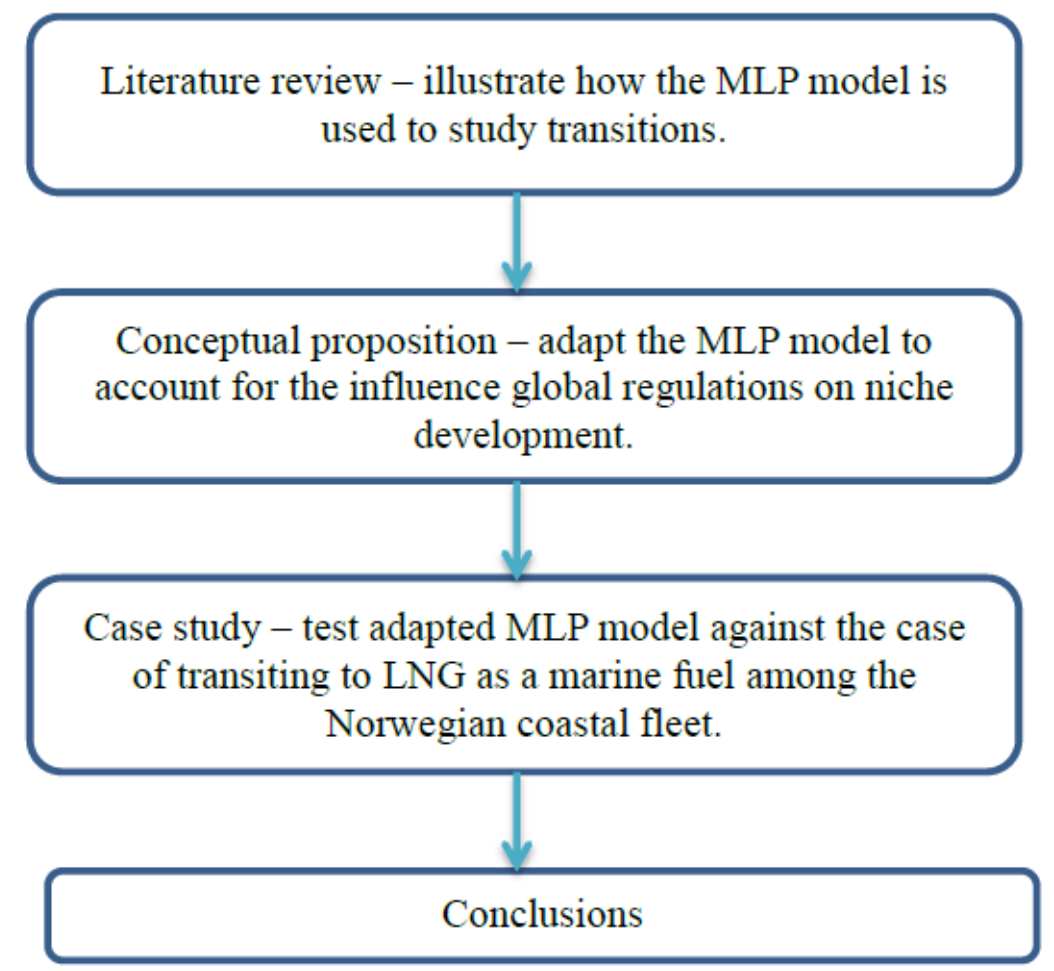

Figure 1. Methodological steps for our study of the multi-level perspective model.

\section{Literature Review}

\subsection{Multi-Level Perspective: A Conceptual Tool for Understanding Sustainability Transitions}

In this paper, we refer to sustainability transitions as long-term, multi-dimensional and fundamental transformation processes through which established socio-technical systems shift to more sustainable modes of production and consumption [8] (p. 956). These shifts between distinctive socio-technical configurations encompassing not only new technologies but also corresponding changes in markets, user practices, policy and cultural discourses as well as governing institutions [9]. We also refer to socio-technical systems as networks of actors (individuals, firms and other organizations and collective actors) and institutions (societal and technical norms, regulations and standards of good practice), as well as material artefacts and knowledge in which each different elements of the system interact, and provide together specific services for society [10] (p. 158). As reminded by Markard et al. [8], transitions studies have developed several conceptual frameworks to analyze the dynamics of socio-technical systems in sectors like electricity or urban water into more sustainable directions [8]. However, the most famous example of a sustainability transition concerns the decarbonization of energy and transport systems [11].

The first analytical analysis of the transition process through different levels was formulated by Rip and Kemp [12]. Following this insight, Rotmans et al. [13] presented a multi-level approach to 
analyze the change in socio-technical systems, which identifies different levels of aggregation where the socio-technical landscapes form the macro-level, the technological regimes form the meso-level and the niches form the micro-level. In these authors view, this multi-level framework might be used to track changes in a system (society or economy) over time, but also to allow comparisons across cases. Geels [1-3] extends the concept of the technological regime, by advancing the notion of socio-technical regimes and by incorporating ideas from sociology on the relationship between various types of institutions and their rules and technological developments [7]. Geels [1] named this model the multi-level perspective (MLP). At the micro-level, niches act as incubation spaces dominated by uncertainty and experimental disorder [14]. These are protected spaces in which actors learn about novel technologies and their uses [1] (p. 1261). At the meso-level, the socio-technical regime is defined by Rip and Kemp [12] as "the coherent complex of scientific knowledge, engineering practices, production process technologies, product characteristics, skills and procedures, established user needs, regulatory requirements, institutions and infrastructures" [12] (p. 330). More precisely, as underlined by Schot and Geels [15] it is an extended version of Nelson and Winter's [16] technological regime, which referred to shared cognitive routines in an engineering community and described patterned developments as "technological trajectories". Sociologists broadened this explanation, arguing that scientists, policymakers, practitioners and special-interest groups also contribute to the patterning of technological development [17]. At the macro-level, the landscape represents the environment external to the regime, and which puts pressure on the regime in various forms as a selective environment [14]. It includes environmental and demographic changes, new social movements, shifts in general political ideology, broad economic restructuring, emerging scientific paradigms, and cultural developments [18]. Hence, the MLP model conceptualizes transitions as the outcome of interactions between these three levels, and a particular relationship between these levels can be understood as a nested hierarchy. Geels [3] stressed that the key point of the MLP model is that transitions come about through the interplay between processes at different levels. Starting with niche innovations that build up internal momentum, changes can then occur at the landscape level which in turn puts pressure on the socio-technical regime, ending with destabilization of the socio-technical regime which creates a kind of windows of opportunity for niche innovations [15]. Therefore, the MLP model does not consider the niche as a static component that grows up without any interactions with its external environment or solely through its internal specifications (e.g., number of users, market shares, etc.). Niche development is the inner process of a larger process which is the transition. Despite its cyclical nature, two patterns are generally put forward in the literature as typical to transitions, and both are strategies to deal with lock-out situations [19].

The first strategy is to apply the new technology in niche markets and improve and build up internal momentum through a process of "niche accumulation" (also called "niche proliferation"). This strategy starts as a radical distinction from the current regime (in terms of markets, technologies, actors involved, institutional arrangement) and aims to prevent early rejection through smart experimentations in niche markets [19]. It usually takes the form of the implementation of protected spaces for more sustainable technologies. These spaces, in the form of technological niches, could function as local breeding spaces for new technologies, in which they get a chance to develop and grow [20]. The new technology can move from one niche market to another ("niche branching") [19]. This improves the fit between technology and markets and increases internal momentum so that a new socio-technical regime emerges. The new technology is then embedded in institutions and social networks and can better compete with the former technology [19]. Indeed, during the process of "niche accumulation", market shares of the innovation (or technology) increase, and more elements are created to support the technology (e.g., infrastructures, regulations, cultural enthusiasm and user practices) [3]. Thus, "niche accumulation" refers to the application of technology in different niche markets so that technology/market combinations become robust [19]. Once the technology is sufficiently developed and broader usage rates are achieved through learning processes and adaptations, then the protective initial environment (e.g., tax exemptions, investment grants, strategic firm investments, etc.) may be withdrawn [21]. 
The second recognized strategy is to start within the existing regime and opt for a radical transformation through a process of "hybridization". This process aims to diverge along the road and bend existing trajectories towards more desirable ones [19], but in a "soft" manner without a quick and radical rupture with the "old" socio-technical regime. Quoting Raven [19] (p. 2395) "Hybridisation refers to the process where "new" and "old" technology hook up to form some kind of a hybrid technical design". Such a "hybridization" process is described in detail by Geels [3] studying the transition from sailing ships to steamships. The author explains that steam engines were initially add-on elements in sailing ships for situations where there was no wind. In the 1840s and 1850s, hybrid ships were built using wind and steam as equal forms of a power source. And after a long period of "hybridization" the new technology (in this case the steam engine) can become the dominant design solution. It is worth noting that both strategies are usually complementary. Any transition strategy in practice will often be a mix of hybridization and niche accumulation [19].

\subsection{Multi-Governance Level: Towards a Top-Down Approach in Considering External Regulation Systems}

It was stated in the introduction that the MLP model has been criticized for over-focusing on technology and for its insufficient consideration of the socio-political aspects of transition [6,7]. Albeit, Geels [2] attempted to conceptualize dynamic interactions between actors, rules and socio-technical systems, where the perceptions and activities of human actors are coordinated, but not determined by institutions and rules. Some authors, such as Avelino and Wittmayer [22], move further in considering the influence of actors and developed a multi-actor perspective to understand transition politics and conceptualize power struggles between actors engaged in sustainability transitions. Farla et al. [23] aimed to provide a closer look at how strategies, resources and firms trigger the transition process, and how these changes feed back into the actor's strategies. Furthermore, several authors argue that the main criteria that may contribute to a successful niche emergence depend on changes in government policy to support them $[2,24]$. In other words, niche development is tightly related to decisions made by policy-makers and the government.

In the present paper, we have deliberately chosen to emphasize the niche concept to understand how a niche market grows up and how "external" and "internal" regulation systems could contribute to its development. We refer to regulation systems as every authority, agency and public administration that set laws, directives and rules applied to a particular sector or industry. Besides, we are mindful that the transition process usually involves a myriad of actors $[22,23]$ and institutions whose individual analysis will go beyond the scope of this paper. Therefore, we will focus much more on the "external" regulation systems (namely international regulations) mainly because the sustainability transition literature sheds less light on it. Moreover, we believe that the globalization phenomenon grants more power to international organizations and thus increases their influence on the national policies of the affiliated countries. This analysis is conducted without neglecting the importance of the other actors in the process of niche development, and as Farla et al. [23] pointed out, there is never only one type of actor involved in transitions processes. That is why we will attempt to approach the concept of policy-decision through the concept of governance which refers to public decision-making. Most of the contributions in transition studies divided actors who participate in governance into three categories, namely, state (government), private sector (market) and civil society actors [25]. Besides, we assume, like some authors [24-28], that considering actors at different levels of governance can be helpful to understand their impact on transitions, and especially niche development. This resonates with the findings of Fischer and Newig's [29] article, where they argue that the local governance actors and the national government are important for niches: local governance actors can be niche managers and the national government can enable a niche creation through institutional work. As Avelino et al. [22] stressed in their article, it is established in the literature that the role of actors in transition researches suffers from some conceptual weaknesses, such as certain vagueness in the reference to actors and their level of aggregation. Therefore, it seems difficult to assign a particular type of actor to a particular structural level. Nevertheless, an attempt of assigning actors to the respective 
spatial levels of decision-making has already been carried out by Fischer and Newig [29]. Let us take a closer look at the actors associated with each category.

Firstly, for the actors on the local and regional governance level (unlike in Hoogh and Marks's [30] typology) we have put together the local and regional governance levels in a sole category, because we believe that it is sometimes difficult to define clearly the influence boundaries between those two governance levels. Local and regional actors include participants in community projects, local organizations, planning agencies or local authorities. Quitzau et al. [31] advocate that the role of local policy-makers engaged in spatial planning is crucial because local initiatives (such as developing infrastructures) have transformative capacities to move local stakeholders in a transition process by giving more credit to the new technological niche or niche market. Indeed, given the scale of the required investments and their high risks, sometimes private investors are unwilling to invest. Then, the main objective of governments is to provide investors with the needed information so that they can decide logically about investment based on it. For instance, through a game theory approach, Babaei et al. [32] demonstrate that by determining the amount of subsidies and intermediate producers' production, governments can reassure investors that their investments will be profitable. In such cases, governments can provide the required conditions for fair competition among the stakeholders that can ensure the process for a smooth transition of the LNG as a sustainable marine fuel within the shipping industry. In the same vein, and with a similar approach, Ray et al. [33] stress the role of pricing strategy as an incentive to reconsider the profitability of a market in the context of supply chain members. In terms of making-decision perspective, the stakeholders should also manage all the risks related to a first-mover strategy. Goswami et al. [34] demonstrate through a Bayesian network approach how the product conception is important for the reliability of the whole project, and especially the associated supply chain risks. Secondly, the actors on the national governance level refer mainly to the national government. This latter has the potential to allocate key resources efficiently by managing priorities and setting national policies and fiscal measures. Thirdly, the global governance level comprises actors such as NGOs, multinational companies and international organizations. With the globalization effects, these kinds of actors seem to have a more important role to play, especially environmental issues.

Figure 2 shows a schematic illustration of the multi-level governance model. It is worth noting that decisions emerging from each governance level will impact directly or indirectly the development of the niche (generally assigned to the local or regional level). For instance, the decisions on the global governance level could probably influence the political environmental mainstream on the national level, whose new environmental policy could influence the local level in its turn (e.g., the "Landscape regime" then the "Socio-technique regime" and finally the "Niche" in Geels's $[1-5,9]$ model). As well as at the national governance level, new environmental government initiatives (e.g., more funds allocated to the renewable energy sector) could probably influence the regional and local levels. Hence, developing a new technology niche or a new niche market will probably require the support of regional planning, new policy initiatives and a suitable global mainstream heading all to the same goal.

\subsection{Niche-Based Analysis: A Global-Local Perspective on the Development of Transition Niches}

Generally, the MLP analysis is realized with historical case studies where the transition process has already been achieved. In such contexts, it can draw on accurate data to establish the changing historical context, often over several decades. The MLP's analytical framework considers the variations with its three levels mainly along two dimensions: a temporal and a structural scale. Keeping in mind that nowadays we are living in an "interconnected" world where the notion of national and local "territorial boundaries" becomes fuzzier, analyzing niche developments and changes without taking account international issues (environment, economics, political, etc.) may likely lead to simplistic or incorrect analytical assumptions and empirical analysis [35]. In the view of Geels [1-5], the landscape level (which is the higher level in Geels's representation) comprises essentially the ideological mainstream and the international context that surround a technological innovation and which have the power to influence (positively or negatively) the regime level: in the words of Schot and Geels [36] "to put 
pressure on the existing socio-technical regime level" [36] (p. 401). The socio-technical regime could also put pressure on the niche level. However, following Geels's conception, the niche has already been implemented, and could be impacted by the landscape regime. However, what if "exogenous context" generates the niche emergence? As previously mentioned (Section 2.2), we chose intentionally to emphasize a specific level of the MLP analytical analysis, namely the niche level (and attempted to conceptualize the early stage of the niche accumulation). This choice was motivated by three main reasons: first, the niches constitute the starting point of the transition process not only through the lens of the MLP approach [1-3,21] but also through the strategic niche management literature [15,21]. Secondly, the niche has an important role to play in the success of the transition process by facilitating new technologies spreading to new markets. Therefore, it is important to pay particular attention to the factors that could reinforce the development of this niche. Finally, in cases where the transition process is at the early stages (like our case study), it is difficult to yield a distinct analysis of the whole process at the three different levels. Therefore, in this paper, we attempt to complement the MLP model without rejecting it and argue that in some cases, the international context through supranational organizations could generate the ideal conditions for niche emergence, either by strict regulations or by implementing protective areas under international organization monitoring where technological or market niches could find suitable conditions to emerge. Thus, conceptually, we suggest analyzing the niche development by pushing the structural dimension beyond the national boundaries. In our view, in the context of globalization, the international level (see the dotted arrow on the vertical axis in Figure 3, the landscape level part and the part above) has an important role to play. In this view, we advocate opting for a global-local perspective, where the niche represents the "local" level (like in the MLP model) and where the supranational niche (settled by international regulation systems) might represent the "global" level.

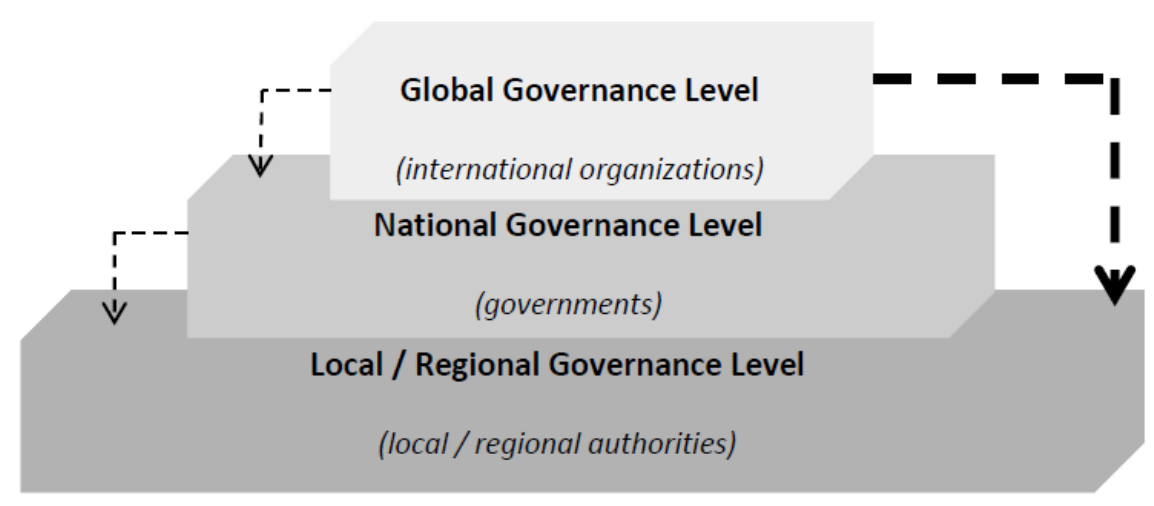

Figure 2. Governance levels as nested hierarchy. Source: elaborated by the authors.

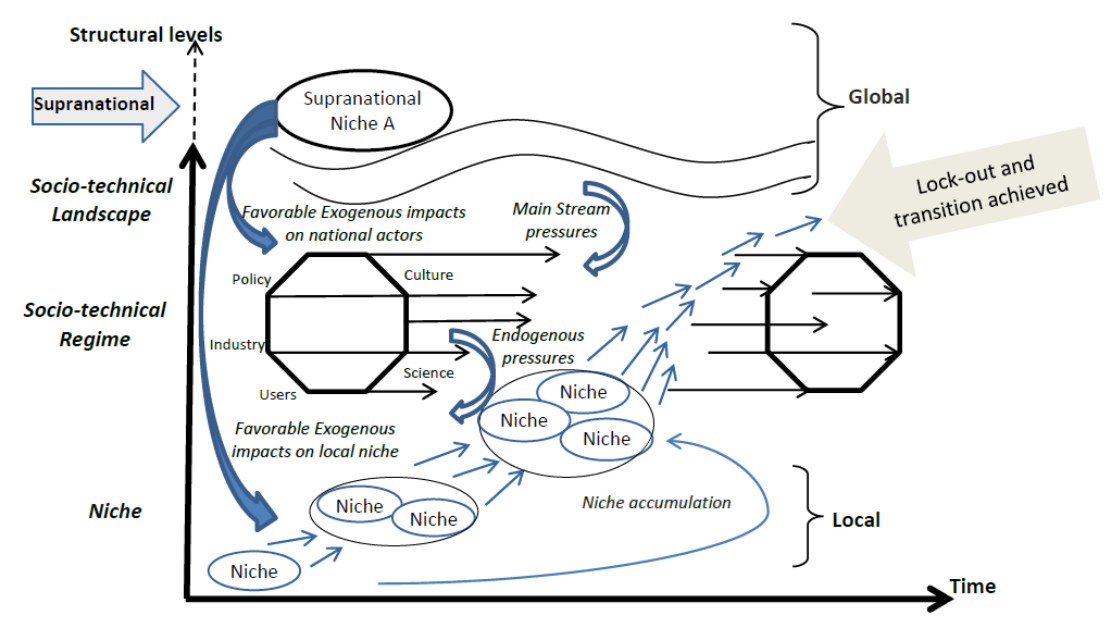

Figure 3. Global-local niche development. Source: from Geels [1] adapted by the authors. 


\section{Case Study: Sustainable Transition of LNG as Marine Fuel in Norwegian Shipping}

The choice of the transition to LNG as a marine fuel in Norwegian shipping was motivated by several reasons: Above all, Norway is considered a leader or "early adopter" in terms of LNG utilization as a marine fuel, and the transition process is well-advanced in this Nordic country. Moreover, Norway is a country with abundant resources in fossil energy and especially gas. Lastly, the Norwegian case is a very well-documented one when compared to some other countries where LNG transition is taking place. According to Yin [37], "the case study method is most likely to be appropriate for 'why' and 'how' research questions". In the present paper, we adopt the case study to examine in a top-down approach how an "external" regulation system (e.g., international regulations) could impact niche development toward a sustainability transition (e.g., LNG as marine fuel). To do this, the case study data were collected from two sources.

The first source of data comes from specialized websites offering vessel tracking information (namely, vesselfinder.com, marinetraffic.com and scheepvaartwest.be). From these sources, we built a list of dual fuel and LNG-fueled vessels deployed in Norwegian coastal trade and operating under the Norwegian flag. A database was compiled identifying for each vessel in the list the following: the type of vessel, the port of registry, the year of entry in activity, the type of engine (the type of propulsion engine) and the operating owner. These data form the basis for the first part of the case study.

The second source of data group is international organization reports (e.g., International Maritime Organisation), Norwegian public administration reports (e.g., Norwegian Ministries) and think-tank studies from established research organizations (e.g., Oxford Institute for Energy). Data were collected on international regulations, national public initiatives or policies, but also on specific programs, plans or projects implemented at the local or regional level concerning the use of LNG as a marine fuel in Norwegian shipping.

\subsection{LNG as a New Marine Fuel in Norway: State of Affairs 2001-2018}

Over the two past decades, Norway has built LNG powered vessels and is currently building additional ones. Such keen interest is mainly explained by the fact that LNG-fuel is considered by many users as an environmentally and commercially feasible alternative to oil-based shipping fuels. Firstly, LNG provides significant environmental benefits by being one of the best ways to reduce sulfur oxide (SOx) and nitrogen oxide (NOx) emissions. Indeed, LNG fuel emission provides a 20 to $25 \%$ reduction in greenhouse gas (CO2), about an 80\% reduction in NOx and a 100\% reduction in SOx and particulate matters (PM) [38]. It is worth noting that the emissions of NOx are governed by combustion process parameters, and these emissions will vary depending on the engine technology and are not directly related to the fuel $[39,40]$. Nevertheless, LNG remains the cleanest fossil fuel currently available in maritime transportation. It is not a perfect solution. Indeed, while LNG contains less carbon per unit of energy than conventional marine fuels, its use might not reduce greenhouse gas (GHG) emissions on a life-cycle basis [41,42]. Alternatively, when one includes well-to-tank (from extraction through logistics to the vessel's tanks) estimates of emissions for the LNG supply chain, the resulting additional emissions will reduce and, in the worst case, more than nullify any GHG gains from LNG relative to heavy fuel oil (HFO) or marine gas oil (MGO) [40]. Similarly, the overall and long-term gains from using LNG as a marine-fuel are questioned, in particular due to the impact of methane slip during the storing of LNG [43]. However, for its potential rapid gains and implementation, its matches perfectly with the International Maritime Organization's (IMO) agenda, which introduced in January 2020 a $0.5 \%$ sulfur limit on fuel oil used by ships operating outside designated SOx emission control areas (SECAs). Thus, when LNG is chosen as the fuel for any new-built vessels, it fulfills all the IMO air emission regulations [44]. Secondly, LNG provides substantial economic gains and is considered as a cost-effective marine fuel since it is competitively priced long term when compared to other fuels and generates lower operational and maintenance costs [45].

Norway is considered a pioneer in the development of the LNG-fueled ship. As of late 2019, most of the LNG-fueled ships in operation worldwide are sailing under the Norwegian flag. The development 
of the Norwegian LNG-fueled fleet is shown in Figure 4. We elected to show time series only up to 2018. However, an overview of launching and ordering news in the shipping press clearly suggests that the growing trend in LNG and dual-fuel ships is sustained in the more recent years. The curve and the diagrams suggest the number of cumulated LNG-fueled ships for each year. These numbers also include retrofitting ships to dual-fuel system propulsion or straight LNG system propulsion. As of 1st October 2018, there were 61 vessels in operation using LNG as fuel and sailing under the Norwegian flag. In regard to market segments, ferry vessels and platform supplier vessels (PSV) account for the majority of LNG-fueled ships; they represent almost $40 \%$ and $31 \%$, respectively, of the totality.

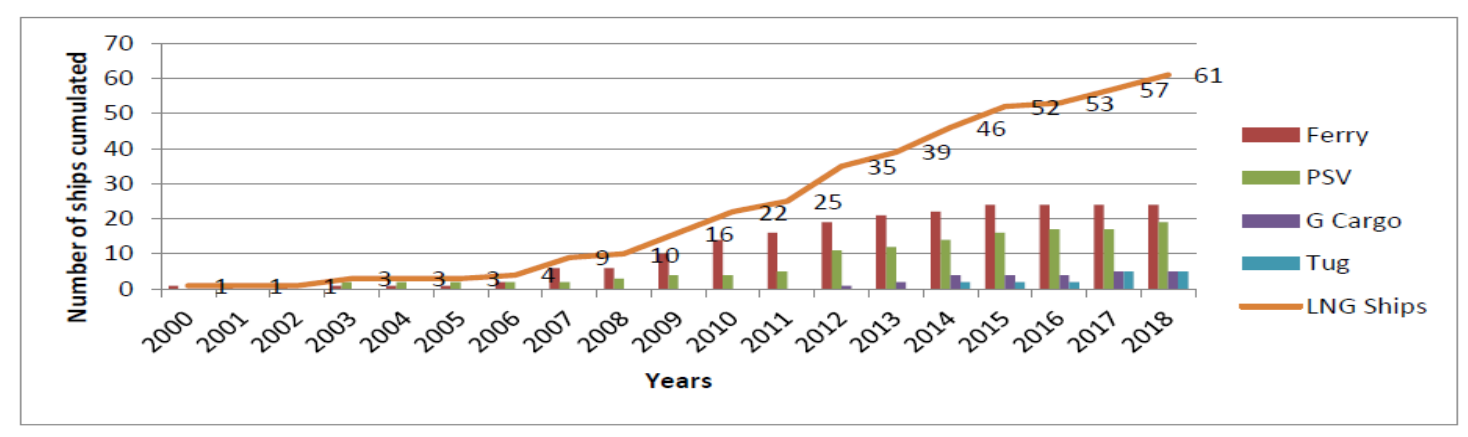

Figure 4. Development of Norwegian dual and liquefied natural gas (LNG)-fueled fleet (2000-2018). Source: adapted by Zhongying and Sandholt [46].

The shipping industry obits to a two-fold agenda, the national one established by the Norwegian public authorities, and the international one settled by the IMO which rules a large part of the international shipping regulations (e.g., MARPOL). Indeed, the development of the LNG-fueled ships in Norway was driven by the environmental considerations and financial incentives from the Norwegian government. Norway has been very successful in encouraging the maritime industry to invest in NOx reducing technology. The main driver for this initiative is the environmental requirements mandated by MARPOL on the limitations of NOx emissions. Since August 2012, the Baltic Sea and the North Sea are regulated as emission control areas (ECAs), limiting the amount of NOx emissions. While the use of LNG fuel involves new, higher technology and additional safety considerations, the use of LNG as a marine fuel for non-LNG cargo vessels is now part of normal marine practice in Norway following the introduction of the first LNG car/passenger ferry 19 years ago.

\subsection{Niche Accumulation and Hybridisation Strategies: Ferry Segment and Dual-fuel Utilization}

Before 2011, all of the LNG-fueled ships operating in Norway were car/passenger ferries or platform supply vessels (PSV). The ferry segment is the oldest LNG-fueled segment and the more important one because it induces a large part of the transport network in Norway. Ferries are vessels using Ro-Ro (roll-on-roll-off) technology to transport cars and accommodate passengers on a regular sailing route and schedule. The first LNG-fueled vessel in Norway was a car/passenger ferry. MF "Glutra" (the name of this vessel) was the world's first LNG ferry operated by the Norwegian company "Fjord Line". The MF "Glutra" was initially a prototype. The vessel is DNV-GL classed and marked the first development of technical rules specifically developed for gas-fueled vessels of this type. The company "Fjord Line" started operating MF "Glutra" in Møre og Romsdal County in 2000. The other important segment in Norway is the platform supply vessels (PSV). PSV are service vessels used in the offshore oil and gas industry. These vessels operate under harsh weather conditions in the North Sea and require both large cargo capacity and engine power. Norway has a large PSV fleet due to the country's large offshore industry. Offshore vessels are also a large component of the Norwegian shipbuilding industry. The PSV segment is another type of vessels particularly suited for LNG propulsion because they often operate in environmentally sensitive areas, but on short routes close to the coast. These sensitive areas with heavy traffic benefit especially from the reduction of pollution by harmful exhaust emissions. 
After 2011, as shown in Figure 5, the utilization of LNG as a marine fuel has gained other niche market segments (e.g., chemical, oil, gas, containers, bulk, etc.), and its use spreads around the industry. It is worth noting that economic considerations might also explain LNG fuel attraction in a certain industry. For instance, bulk carriers transport bulk cargo, such as grain, iron ore, coal or liquids. Since the focus in the bulk cargo market is generally on low-cost transport [47], the financial consequences of shifting to LNG propulsion are especially interesting to this segment. Nevertheless, within the current fleet of LNG-fueled ships, the car/passenger ferry segment is still the largest one (with 24 ships of 61). The option of using LNG as a fuel is attractive for this type of vessel because of the operating profile, as well as for economic, regulatory and environmental reasons [45]. Indeed, most of the ferries operate near the coastline which is considered an environmentally sensitive area, and where eco-friendly powered vessels could better be matched.

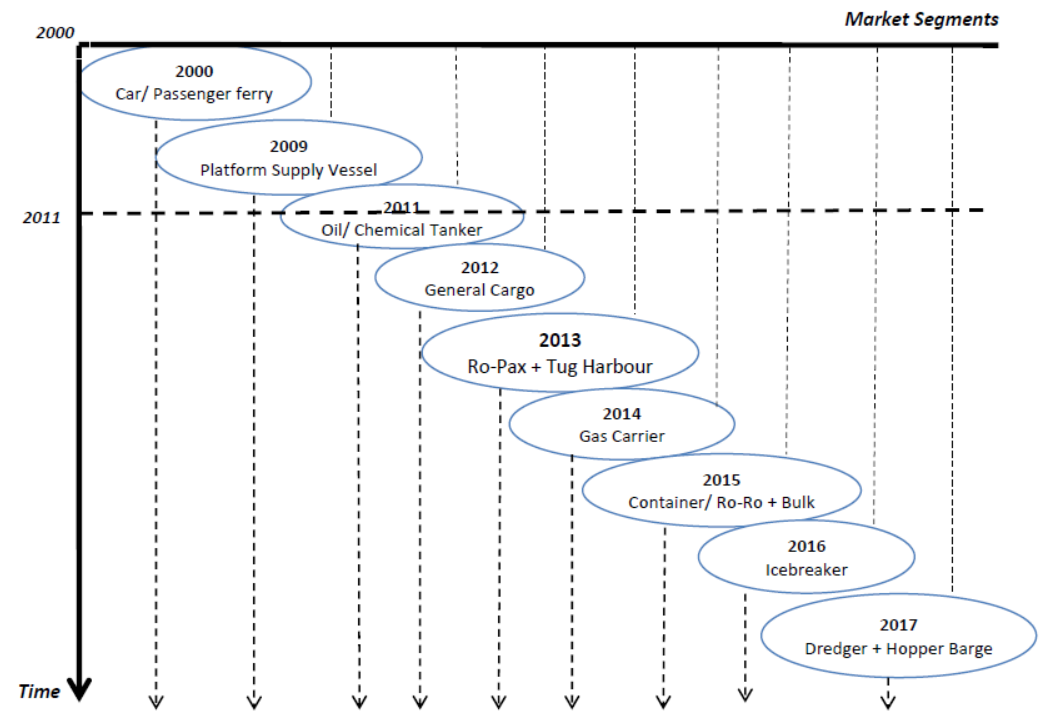

Figure 5. LNG-fueled ship niche accumulation in Norway. Source: the authors from cited references.

The wide utilization of LNG as a marine fuel in Norway since 2000 cannot be separated from the international and national environmental issues, but also from to hybridization strategies used in the early years of the LNG transition. Hybridization means that the current technological regime has not completely switched yet in the new technology, but users still use the old technology in certain cases. Concerning the LNG-fuel transition into the shipping industry, hybridization in this case is embodied by the use of dual-fuel engines. Vessels equipped with such dual-fuel engines can operate on either gas or diesel fuel. Such a hybridization strategy is itself linked with two main maritime owners' strategies for fleet development, namely retrofitting (adding new technology to an older vessel) or building vessels to replace those currently deployed and operating with the previous generation of technological characteristics. Indeed, the maritime owners might choose between retrofitting the current fleet or building new ships equipped with the new LNG propulsion technology. The investment cost differs for the different compliance strategies, for retrofit or new builds and is partly proportional to the size of the propulsion plant [48]. According to IMO [48], for instance, in the case of two-stroke dual-fuel engines, the investment cost will be $700 \mathrm{USD} / \mathrm{KW}$ to retrofit a vessel against $1500 \mathrm{USD} / \mathrm{KW}$ to build a new vessel. In the case of four-stroke dual-fuel engines, the investment cost will be $800 \mathrm{USD} / \mathrm{KW}$ to retrofit a vessel against $1600 \mathrm{USD} / \mathrm{KW}$ to build a new vessel. Hence, it will cost half less to retrofit a vessel for an owner compared to build a new one with dual-fuel propulsion technology.

As shown in Table 1 (see below), of the 61 LNG-fueled vessels in operation in 2018, 31 vessels are "dual fuel" (52\%), 30 vessels are "straight LNG" $(48 \%)$. Moreover, around half of the straight LNG-fueled ships are ferries, and more than half of the dual-fueled ships are PSV. The ferry ship segment is especially suited for LNG propulsion. Indeed, those vessels often operate in environmentally 
sensitive areas close to the coast. These sensitive areas with heavy traffic benefit especially from the reduction of pollution to water and harmful exhaust emissions [48]. In contrast, the PSVs are more suited to dual-fuel propulsion because those vessels must switch between high speed (into the deep sea) and low speed (near sea shores). These speed variations are generally facilitated by vessels equipped with dual-fuel propulsion systems [45].

Table 1. Straight LNG and dual-fuel engines in Norwegian coastal shipping.

\begin{tabular}{ccccc}
\hline Type of Engine & Pure LNG & Percentage (\%) & Dual Fuel & Percentage (\%) \\
\hline Type of Vessel & \multicolumn{5}{c}{} \\
\hline Ferry & 16 & $53.3 \%$ & 8 & $25.8 \%$ \\
PSV & 2 & $6.6 \%$ & 17 & $54.8 \%$ \\
General Cargo & 5 & $16.6 \%$ & 0 & 0 \\
Tug & 2 & $6.6 \%$ & 3 & $9.6 \%$ \\
Oil/Chemical & 3 & $10 \%$ & 0 & 0 \\
Ro-Ro Pax & 2 & $6.6 \%$ & 0 & 0 \\
Other services & 0 & 0 & 3 & $9.6 \%$ \\
\hline Total & 30 & $100 \%$ & 31 & $100 \%$ \\
\hline
\end{tabular}

Source: adapted by Zhongying and Sandholt [46].

\subsection{Global-Local Niche Analysis: From Emission Control Areas (ECAs) to Local Niche Segments}

Two different regulation levels played an important role to create suitable conditions for LNG fuel niches to develop in Norway. At the global (or supranational) level, the development of LNG as a marine fuel in Norway has been impacted by the environmental agenda of international institutions, namely the IMO in charge of the international shipping regulation. The specific unit of the IMO in charge of maritime pollution is the so-called MARPOL (with its different Annexes, each one refers to specific maritime harm). MARPOL Annex VI, first adopted in 1997, limits the main air pollutants contained in the ship's exhaust gas, including SOx and NOx, and prohibits deliberate emissions of ozone-depleting substances (ODS). Following the entry into force of MARPOL Annex VI on 19 May 2005, the Marine Environment Protection Committee (MEPC) agreed to revise MARPOL Annex VI to significantly strengthen the emission limits in light of technological improvements and implementation experience [49]. MEPC adopted the revised MARPOL Annex VI and the associated NOx Technical Code 2008, which entered into force on 1 July 2010 [50]. The main changes to MARPOL Annex VI (or revisited MARPOL Annex VI) are a progressive reduction globally in emissions of SOx, Nox, PM and the introduction of the emission control areas (ECAs) to reduce emissions of those air pollutants further in designated sea areas. An ECA is a specific sea area, including port areas, designated by the IMO in accordance with criteria and procedures set forth in Appendix III to Annex VI, in which more stringent emission regulations have been established [51]. Under the revised MARPOL Annex VI, the global SOx limit will be reduced from the current 3.50\% to $0.5 \%$, effective from 1 January 2020. The limits applicable in ECAs for SOx and PM were reduced to 0.1\%, from 1 January 2015 [50]. There are currently four designated ECAs: The Baltic Sea, the North Sea, the North American and the US Caribbean Sea. The North Sea ECA (which concerns Norway) is defined in MARPOL Annex V.

As shown on Figure 6 (see below), the European side of the EACs includes the Baltic Sea (SOx, adopted 1997; enforced 2005) and the North Sea (SOx, adopted 2005; enforced 2006). Both areas are regulated as ECAs also limiting the amount of NOx emissions. MARPOL Annex VI requires NOx reduction to meet Tier II requirements (20\% reduction) by 2011, and Tier III requirements (80\% reduction) by 2016 apply to the North American and US Caribbean ECAs, but by 2021 apply to the Baltic Sea and the North Sea. Moreover, the MEPC decided at its 70th session in London that the implementation date for the $0.5 \%$ global SOx cap is set in 2020. This new IMO regulation extends the current ECAs to all Norwegian ports along the coastline (see the grey shaded area on Figure 6). The latest resolution related to the ECAs was the MEPC.286(71), which was adopted on 7 July 2017 
and which designated the Baltic Sea and the North Sea ECAs for NOx Tier III control [52]. While SOx restrictions are already applicable in all ECAs for all ships (effective from November 2017), a NOx ECA Tier III standard applies only on new ships built on or after January 2021. The Tier III requirements regard all new build vessels that are 500 GT and above, with a length of at least 24 meters and sailing within an ECA. These ships must also feature an engine output of $130 \mathrm{~kW}$ or more. The legislation also applies to a retrofit project by installing an engine with an output of more than $130 \mathrm{~kW}$. They also apply to vessels built after January 1st of 2021 (Baltic Sea and the North Sea ECA).

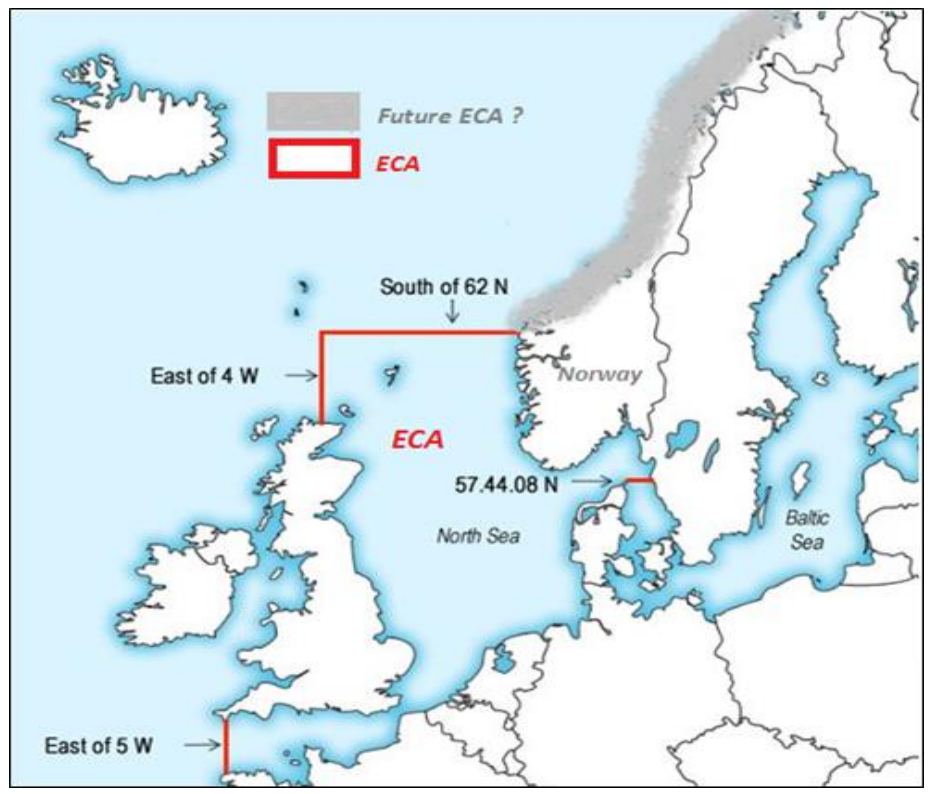

Figure 6. Emission controlled areas (ECAs) in the Norwegian coastline. Source: adapted by DNV-GL [53].

At the national level, the Norwegian government has been very successful in encouraging the maritime industry to invest in NOx-reducing technology. The main driver for this initiative is the NOx Agreement (2008-2017 for its first version), which aimed to encourage the shift to LNG as a marine fuel in Norway. In January 2007, the Norwegian government introduced a new tax on NOx emissions, and 12 months later, launched the Business Sector NOx Fund [54]. The Nox Fund is an environmental agreement between 15 Norwegian business organizations and the Norwegian Ministry of Climate and the Environment. Under this agreement, affiliated enterprises are exempt from the Nox tax, and instead, pay into the Nox Fund. They are entitled to exemption from the Norwegian fiscal regime and its Nox tax of $17.33 \mathrm{NOK} / \mathrm{kg}$ Nox. In return for their commitments to reduce their emissions by at least 34000 tons/year, the affiliated companies pay lower rates into the fund, for instance, shipping pays $4 \mathrm{NOK} / \mathrm{kg}$ Nox [54]. The Fund is then used to provide financial support for Nox reduction measures by enterprises that have paid into the Fund. This support covers additional costs of investing in LNG-fueled ship or Nox reduction measures, such as engine modifications in ships, the use of LNG plus batteries or installation of selective catalytic reduction (SCR) technologies [55]. Thus, the NOx tax targets solely domestic ships. Furthermore, this agreement was recently extended to cover the period of 2018-2025 with stronger incentives. The new NOx agreement brought some changes from the previous one; amongst them, the obligation has been in the form of emission ceilings (previously a reduction of a ton of NOx) of 95000 tons of NOx since 2018. Moreover, the affiliated companies will pay a rate of 6 to $10 \mathrm{NOK} / \mathrm{kg}$ NOx [54]. The authorities can terminate the agreement if NOx emissions are exceeded by $5 \%$ of the emission ceiling, and, finally, the payment rates to the NOx Fund are regulated so that the difference between high rate and the low rate will be reduced. It is worth to note that, 39 of Norway's 61 LNG-propelled vessels listed previously (excluding LNG carriers) have benefitted from financial support from the NOx Fund. Therefore, around two-thirds of Norway's LNG-fueled marine fleet was subsidized by the Norwegian NOx Fund [45]. 
The municipalities (called "Fylke" in Norwegian) are local administrative entities and have the overall responsibility for land-use planning and provision of services within their geographical catchment areas [56]. They have an important role in climate change adaptation, as a number of the challenges will be at a local level. In 2009, guidelines were introduced for climate and energy planning in the municipalities. New guidelines describing how the municipalities can incorporate climate change adaptation work into their planning activities have been developed [56]. At the regional level, the counties also play an important role regarding guidance and coordination of municipal and regional plans. Some municipalities in Norway host landing sites for gas and/or terminals for LNG as well as refueling installation of LNG-fueled ships (e.g., bunkering). The infrastructure issue has been raised by many authors $[57,58]$ because the LNG industry has to struggle with the "chicken and egg" dilemma. Further investment in infrastructure, especially coastal storage, is required to stimulate demand and ease of use. However, the sector is reluctant to invest until the demand materializes. Indeed, as pointed out by Aronietis et al. [59], when facing investment decisions, the ship-owners tend to hedge their bets between available technologies, because this strategy minimizes the risk of choosing the "wrong" technology, and it tends to also come at a higher investment cost. These authors describe the situation as an asymmetric interest perspective between the shipping companies and the bunkering companies. On the one hand, shipping companies will postpone investing in LNG-powered vessels as long as there is uncertainty regarding the availability of LNG at the vessels' ports of call, and the market price of LNG must moreover justify any additional investment required for LNG conversion or new building. On the other hand, bunkering companies will remain reticent to invest in new (or retrofitted) bunkering vessels as long as there are no guarantees that future demand for LNG justifies such financial commitment. The same logic applies to investments in LNG bunkering infrastructure [59]. Moreover, even when the bunkering facilities exist, the maritime carriers will deal with the complexity of bunkering decisions related to the selection of the bunkering ports. Indeed, as well as for diesel fuel or heavy fuel oil (HFO) bunkering, the LNG-fueled maritime companies should integrate the fluctuation of LNG prices and the estimation of bunkered fuel cost before making any decisions [60]. Efficient strategic bunker management has to adapt the navigation by considering the vessel speed [61] to optimize their fuel consumption [62].

The Norwegian Government has allocated considerable resources along with the Norwegian Maritime Authority to support the environmental efforts of the Norwegian maritime industry [63]. Moreover, the roles of Port Authorities have considerably changed over these last few decades, particularly with the emergence of the "green port" concept, which assigns to ports environmental responsibility that goes beyond their traditional landlord and regulatory functions [64]. Amongst these new roles, port authorities could coordinate and facilitate new applications of innovative technologies, e.g., the maritime use of LNG. Indeed, as Wang and Notteboom [64] stressed, port authorities can assume the role of coordinators or facilitators in the development of a regional innovation system by developing an innovation network.

Hence, the development of LNG could be considered as a new way to deal with the environmental issue and add value to this role. In Norway, public port authorities are playing a proactive role in facilitating the use of LNG as a marine fuel. This role is strongly supported by the national government which allocates public funding to any initiatives leading to environmental benefits to the region (e.g., the ENOVA program), and such public funds would not be possible in neighboring countries due to constitutional differences [65]. To facilitate the use of LNG as a marine fuel, Norwegian port authorities have undertaken several initiatives for providing bunkering services with maximal standards of safety. Indeed, while the international shipping community only adopted in 2016 a legislation for crews onboard LNG powered vessels, in Norway, regulations were in place as early as 2002 (see Table 2, regulations no664 concerning ships with gas engines) and required that crews were continually trained to gain the required knowledge to perform their gas-related duties. 
Table 2. Regulations, programs or initiatives regarding LNG-fueled ships in Norway.

\begin{tabular}{|c|c|c|c|c|}
\hline Governance Levels & Institutions or Organizations & Projects, Programs or Laws & Year of Entry into Force & Rational and Goals \\
\hline \multirow[b]{2}{*}{ Global } & \multirow{2}{*}{$\begin{array}{l}\text { I.M.O (International } \\
\text { Maritime Organization) }\end{array}$} & MARPOL Annex IV & (1997) & Regulations aim to reduce harmful emissions from ships. \\
\hline & & Emission control areas & (2000) & $\begin{array}{c}\text { Controlled areas where (Nox) and (Sox) emission levels } \\
\text { are limited. }\end{array}$ \\
\hline \multirow{2}{*}{ Global on Local } & $\begin{array}{c}\text { Ports Authorities } \\
\text { (International Maritime Organization) }\end{array}$ & $\begin{array}{l}\text { International Code of Safety } \\
\text { for Ships using gases and } \\
\text { other low-flashpoint fuels } \\
\text { (IGF Code) }\end{array}$ & (2015) & $\begin{array}{l}\text { To provide an international standard for ships, other than } \\
\text { vessels covered by the IGC Code, operating with gas or } \\
\text { low-flashpoint liquids as fuel. }\end{array}$ \\
\hline & $\begin{array}{c}\text { International Association of Ports and } \\
\text { Harbours (IAPH) } \\
\text { International Organisation } \\
\text { Standardisation (ISO) }\end{array}$ & LNG Bunkering Standards & (2016) & $\begin{array}{l}\text { Set of harmonized standards will ensure that key areas of } \\
\text { the LNG bunkering process are aligned across ports } \\
\text { carrying out LNG bunkering operations. }\end{array}$ \\
\hline \multirow{2}{*}{ National } & \multirow{2}{*}{$\begin{array}{l}\text { N.M.C.E (Norwegian Ministry of } \\
\text { Climate and Environment) }\end{array}$} & NOx Fund (I) & (2008) & \multirow{2}{*}{$\begin{array}{l}\text { All ships operating in Norway pay into the fund. } \\
\text { Shipping companies can then apply for subsidy from the } \\
\text { same fund to finance projects that would help to reduce } \\
\text { Nox emissions from their ships. }\end{array}$} \\
\hline & & NOx Fund (II) & (2018) & \\
\hline National on Regional & $\begin{array}{c}\text { Municipalities } \\
\text { (Norwegian Ministry of Petroleum } \\
\text { and Energy) }\end{array}$ & ENOVA programs & (2001) & $\begin{array}{l}\text { Developing an energy and climate plan is only one of } \\
\text { several processes that are necessary for a municipality to } \\
\text { achieve its targets for energy efficiency, renewable energy } \\
\text { and reduction of greenhouse gas emissions. }\end{array}$ \\
\hline \multirow{2}{*}{ National on Local } & \multirow{2}{*}{$\begin{array}{c}\text { Ports Authorities } \\
\text { (Norwegian Maritime Authorities) }\end{array}$} & $\begin{array}{l}\text { Regulation concerning cargo } \\
\text { ships with natural } \\
\text { gas-fueled engine }\end{array}$ & (2002) & \multirow{2}{*}{$\begin{array}{l}\text { Regulations with mandatory requirements for training } \\
\text { officers and crew of LNG-fueled vessels. }\end{array}$} \\
\hline & & $\begin{array}{l}\text { Regulation concerning the } \\
\text { construction and operation of } \\
\text { gas-fueled passenger ships }\end{array}$ & (2005) & \\
\hline
\end{tabular}

Source: adopted by the authors from cited references. 
This includes the requirements for (i) crews to undertake basic gas-related training and conduct periodic gas-related drills, and (ii) companies to prepare and maintain a training plan and manual [66]. Table 2 summarizes the main settled programs and initiatives dealing with LNG as marine fuel in Norway.

\section{Conclusions}

This paper endeavored to highlight how international regulation could impact local transition niche development. The global level which comprises international organizations whose influence widens in the current globalization context should be taken into account at the national and local level. Since many of the most pressing environmental issues are global by nature, international organizations that regulate the environmental externalities gain a certain kind of legitimacy and overall a responsibility to press the national governments in more environmentally friendly orientations. Therefore, in this paper, three main points have been argued.

First, the critical review of the literature and the case study presented allow us to propose an important yet subtle adaptation to multi-level perspective (MLP) models to study niches in sustainability transition. Unlike the standard MLP conceptualization, we tested a top-down approach, where the local level (the niche within the MLP model) is still the core of the transition process, but where the transition process is not impacted by the local level but appears to be triggered at the global level.

Second, we argue that in some cases, international regulation can provide suitable conditions for a local niche to emerge and be subsequently developed. Indeed, the LNG as a marine fuel matches perfectly with the IMO agenda, which set 2020 as the implementation date for the $0.50 \%$ sulfur limit on fuel oil used by ships operating outside designated SOx emission control areas (SECAs).

Third, the case of Norwegian LNG transition in shipping demonstrated that stricter international regulations implemented in early times can positively impact maritime carriers and convince them more easily to "jump" toward a new type of energy propulsion. We argue that initially, it was IMO's restricted emission schemes in coastal waters worldwide that established suitable conditions for Norwegians authorities to support and promote concrete initiatives with programs offering financial support for innovators, transporters and users who endeavored to adopt LNG as a marine for fuel for their operations. Obviously, the success of Norway with LNG as an alternative marine fuel cannot be attributed to a single reason but results from several factors, such as the financial incentives from the Norwegian government encouraging the maritime industry to invest in NOx reducing technology. The prevalence of shipping routes with predictable journey patterns in coastal trade should also not be ignored, as it is a condition potentially impossible to transfer in many international shipping markets. Norway's energy abundance has certainly contributed to the development of LNG in this country.

Future studies will probably indicate whether the LNG is a feasible alternative to other marine fuels on the global scale, but stricter international regulation seems to be the main driver of the changing socio-technological system. Finally, our study could offer an interesting tool to study other transition niches in other socio-economic settings or within different industrial sectors.

Author Contributions: Conceptualization, S.L. and E.G.; methodology, S.L. and E.G.; validation, S.L. and E.G.; formal analysis, S.L. and E.G.; resources, S.L. and E.G.; data curation, S.L. and E.G.; writing-original draft preparation, S.L. and E.G.; writing-review and editing, S.L. and E.G.; visualization, S.L. and E.G.; supervision, S.L. and E.G. All authors have read and agreed to the published version of the manuscript.

Funding: This research received no external funding.

Conflicts of Interest: The authors declare no conflict of interest.

\section{References}

1. Geels, F.W. Technological transitions as evolutionary reconfiguration processes: A multi-level perspective and a case-study. Res. Policy 2002, 31, 1257-1274. [CrossRef]

2. Geels, F.W. From sectoral systems of innovation to socio-technical systems. Res. Policy 2004, 33, 897-920. [CrossRef] 
3. Geels, I.F.W. The dynamics of transitions in socio-technical systems: A multi-level analysis of the transition pathway from horse-drawn carriages to automobiles (1860-1930). Technol. Anal. Strat. Manag. 2005, 17, 445-476. [CrossRef]

4. Geels, F.W. A socio-technical analysis of low-carbon transitions: Introducing the multi-level perspective into transport studies. J. Transp. Geogr. 2012, 24, 471-482. [CrossRef]

5. Geels, F.W. Transformations of Large Technical Systems. Sci. Technol. Hum. Values 2007, 32, 123-149. [CrossRef]

6. Smith, A.; Stirling, A.; Berkhout, F. The governance of sustainable socio-technical transitions. Res. Policy 2005, 34, 1491-1510. [CrossRef]

7. Genus, A.; Coles, A.-M. Rethinking the multi-level perspective of technological transitions. Res. Policy 2008, 37, 1436-1445. [CrossRef]

8. Markard, J.; Raven, R.R.; Truffer, B. Sustainability transitions: An emerging field of research and its prospects. Res. Policy 2012, 41, 955-967. [CrossRef]

9. Geels, F.W.; Hekkert, M.P.; Jacobsson, S. The dynamics of sustainable innovation journeys. Technol. Anal. Strat. Manag. 2008, 20, 521-536. [CrossRef]

10. Weber, M. Transforming Large Socio-technical Systems towards Sustainability: On the Role of Users and Future Visions for the Uptake of City Logistics and Combined Heat and Power Generation. Innov. Eur. J. Soc. Sci. Res. 2003, 16, 155-175. [CrossRef]

11. Verbong, G.; Geels, F. The ongoing energy transition: Lessons from a socio-technical, multi-level analysis of the Dutch electricity system (1960-2004). Energy Policy 2007, 35, 1025-1037. [CrossRef]

12. Rip, A.; Kemp, R.; Kemp, R. Technological Change. Hum. Choice Clim. Chang. 1998, 2, 327-399.

13. Rotmans, J.; Kemp, R.; Van Asselt, M. More evolution than revolution: Transition management in public policy. Foresight 2001, 3, 15-31. [CrossRef]

14. Coenen, L.; Benneworth, P.; Truffer, B. Toward a spatial perspective on sustainability transitions. Res. Policy 2012, 41, 968-979. [CrossRef]

15. Schot, J.; Geels, F.W. Strategic niche management and sustainable innovation journeys: Theory, findings, research agenda, and policy. Technol. Anal. Strat. Manag. 2008, 20, 537-554. [CrossRef]

16. Nelson, R.R.; Winter, S.G. An Evolutionary Theory of Economic Change; Harvard University Press: Boston, MA, USA, 1982.

17. Cozzens, S.E.; Bijker, W.E.; Hughes, T.P.; Pinch, T. The Social Construction of Technological Systems: New Directions in the Sociology and History of Technology. Technol. Cult. 1989, 30, 705. [CrossRef]

18. Smith, A.; Voß, J.-P.; Grin, J. Innovation studies and sustainability transitions: The allure of the multi-level perspective and its challenges. Res. Policy 2010, 39, 435-448. [CrossRef]

19. Raven, R.R. Niche accumulation and hybridisation strategies in transition processes towards a sustainable energy system: An assessment of differences and pitfalls. Energy Policy 2007, 35, 2390-2400. [CrossRef]

20. Kemp, R.; Rip, A.; Schot, J. Constructing transition paths through the management of niches. In Path Dependence and Creation; Lawrence Erlbaum: Mahwah, NJ, USA, 2001; pp. 269-299.

21. Kemp, R.; Schot, J.J.; Hoogma, R. Regime shifts to sustainability through processes of niche formation: The approach of strategic niche management. Technol. Anal. Strat. Manag. 1998, 10, 175-198. [CrossRef]

22. Avelino, F.; Wittmayer, J.M. Shifting Power Relations in Sustainability Transitions: A Multi-actor Perspective. J. Environ. Policy Plan. 2016, 18, 628-649. [CrossRef]

23. Farla, J.; Markard, J.; Raven, R.R.; Coenen, L. Sustainability transitions in the making: A closer look at actors, strategies and resources. Technol. Forecast. Soc. Chang. 2012, 79, 991-998. [CrossRef]

24. Kemp, R.; Loorbach, D.; Rotmans, J. Transition management as a model for managing processes of co-evolution towards sustainable development. Int. J. Sustain. Dev. World Ecol. 2007, 14, 78-91. [CrossRef]

25. Grin, J. Understanding transitions from a governance perspective, Part III. In Transitions to Sustainable Development, New Directions in the Study of Long Term Transformative Change; Grin, J., Rotmans, J., Schot, J., Eds.; Routledge: New York, NY, USA, 2010.

26. Shove, E.; Walker, G. Caution! Transitions Ahead: Politics, Practice, and Sustainable Transition Management. Environ. Plan. A Econ. Space 2007, 39, 763-770. [CrossRef]

27. Meadowcroft, J. Engaging with the politics of sustainability transitions. Environ. Innov. Soc. Transitions 2011, 1, 70-75. [CrossRef]

28. Kern, F. The discursive politics of governing transitions towards sustainability: The UK Carbon Trust. Int. J. Sustain. Dev. 2012, 15, 90. [CrossRef] 
29. Fischer, L.-B.; Newig, J. Importance of Actors and Agency in Sustainability Transitions: A Systematic Exploration of the Literature. Sustainability 2016, 8, 476. [CrossRef]

30. Hooghe, L.; Marks, G. Unraveling the central state, but how? Types of multi-level governance. Am. Political Sci. Rev. 2003, 97, 233-243.

31. Quitzau, M.-B.; Hoffmann, B.; Elle, M. Local niche planning and its strategic implications for implementation of energy-efficient technology. Technol. Forecast. Soc. Chang. 2012, 79, 1049-1058. [CrossRef]

32. Babaei, M.; Asgarian, F.; Jamali, M.-B.; Rasti-Barzoki, M.; Piran, J. A game theoretic approach for pricing petroleum and determining investors' production volume with the consideration of government and intermediate producers. Sustain. Energy Technol. Assessments 2020, 42, 100825. [CrossRef]

33. Ray, A.; De, A.; Mondal, S.; Wang, J. Selection of best buyback strategy for original equipment manufacturer and independent remanufacturer-game theoretic approach. Int. J. Prod. Res. 2020,1-30. [CrossRef]

34. Goswami, M.; Daultani, Y.; De, A. Decision Modeling and Analysis in New Product Development Considering Supply Chain Uncertainties: A Multi-Functional Expert Based Approach. Expert Syst. Appl. 2020, 114016. [CrossRef]

35. Raven, R.; Schot, J.; Berkhout, F. Space and scale in socio-technical transitions. Environ. Innov. Soc. Transit. 2012, 4, 63-78. [CrossRef]

36. Schot, J.; Geels, F.W. Niches in evolutionary theories of technical change. J. Evol. Econ. 2007, 17, 605-622. [CrossRef]

37. Yin, R.K. Case Study Research and Applications: Design and Methods; Sage publications: Newbury Park, CA, USA, 2009.

38. OECD. Fuelling Maritime Shipping with Liquefied Natural Gas: The Case of Japon I.T.F.P.P. 49; Organisation for Economic Co-operation and Development: Paris, France, 2018.

39. Stenersen, D.; Thonstad, O. GHG and NOx Emissions from Gas Fuelled Engines. Mapping, Verification, Reduction Technologies; SINTEF Ocean AS: Trondheim, Norway, 2017.

40. Lindstad, E.; Eskeland, G.S.; Rialland, A.; Valland, A. Decarbonizing Maritime Transport: The Importance of Engine Technology and Regulations for LNG to Serve as a Transition Fuel. Sustainability 2020, 12, 8793. [CrossRef]

41. Thinkstep. Life Cycle GHG Emission Study on the Use of LNG as Marine Fuel. 2019. Available online: https://www.thinkstep.com/content/life-cycle-ghg-emission-study-use-lng-marine-fuel-1 (accessed on 10 November 2020).

42. Pavlenko, N. The Climate Implications of Using LNG as a Marine Fuel; Working Paper; International Council on Clean Transportation: Washington, DC, USA, 2020.

43. Ushakov, S.; Stenersen, D.; Einang, P.M. Methane slip from gas fuelled ships: A comprehensive summary based on measurement data. J. Mar. Sci. Technol. 2019, 24, 1308-1325. [CrossRef]

44. Lindstad, H.E.; Rialland, A. LNG and Cruise Ships, an Easy Way to Fulfil Regulations-Versus the Need for Reducing GHG Emissions. Sustainability 2020, 12, 2080. [CrossRef]

45. OIES. LNG Supply Chains and the Development of LNG as a Shipping Fuel in Northern Europe; OIES: Oxford, UK, 2019; p. 30.

46. Zhongying, W.; Sandholt, K. Thoughts on China's energy transition outlook. Energy Transit. 2019, 3, 59-72. [CrossRef]

47. Stopford, M. Maritime Economics; Routledge: New York, NY, USA, 2009.

48. IMO. Studies of the Feasibility and Use of LNG as a Fuel for Shipping; International Marine Organization: London, UK, 2016; p. 284.

49. IMO. Presentation of Air Pollution from Ships. 2019. Available online: http://www.imo.org/en/ourwork/ environment/pollutionprevention/airpollution/pages/air-pollution.aspx (accessed on 15 October 2020).

50. IMO. Air Pollution from Ships Cut, with Entry into Force of MARPOL Amendments 2019. Available online: http://www.imo.org/en/MediaCentre/PressBriefings/Pages/MARPOL-Annex-VI-EIF.aspx\# .XOR0oFJKjIU (accessed on 21 October 2020).

51. Čampara, L.; Hasanspahić, N.; Vujičić, S. Overview of MARPOL ANNEX VI regulations for prevention of air pollution from marine diesel engines. SHS Web Conf. 2018, 58. [CrossRef]

52. International Maritime Organization. MARPOL Consolidated Edition 2017; IMO: London, UK, 2017.

53. DNV-GL. In Focus-LNG as Ship Fuel: Latest Developments and Projects in the LNG Industry; DNV-GL: Oslo, Norway, 2015. 
54. Norwegian Ministry of Climate and Environment. Norwegian Policy to Mitigate Climate Changes and Reduce Emissions of Nitrogen Oxides (NOx)-Summary; Norwegian Ministry of Climate and Environment: Oslo, Norway, 2017.

55. NOx-Fondet. About the NOx Fund 2018. Available online: https://www.nho.no/samarbeid/nox-fondet/thenox-fund/articles/about-the-nox-fund/ (accessed on 15 November 2019).

56. Norwegian Ministry of Climate and Environment. Norway's Seventh National Communication: Under the Framework Convention on Climate Change; Norwegian Ministry of Climate and Environment: Oslo, Norway, 2018; p. 460.

57. Wang, S.; Notteboom, T. LNG as a ship fuel: Perspectives and challenges. Global Issues 2013, 60, $15-17$.

58. Calderón, M.; Illing, D.; Veiga, J. Facilities for Bunkering of Liquefied Natural Gas in Ports. Transp. Res. Procedia 2016, 14, 2431-2440. [CrossRef]

59. Aronietis, R.; Sys, C.; Van Hassel, E.; Vanelslander, T. Forecasting port-level demand for LNG as a ship fuel: The case of the port of Antwerp. J. Shipp. Trade 2016, 1, 2. [CrossRef]

60. De, A.; Choudhary, A.; Türkay, M.; Tiwari, M.K. Bunkering policies for a fuel bunker management problem for liner shipping networks. Eur. J. Oper. Res. 2019. [CrossRef]

61. De, A.; Wang, J.; Tiwari, M.K. Fuel Bunker Management Strategies Within Sustainable Container Shipping Operation Considering Disruption and Recovery Policies. IEEE Trans. Eng. Manag. 2019, 1-23. [CrossRef]

62. Ghosh, S.; Lee, L.H.; Ng, S.H. Bunkering decisions for a shipping liner in an uncertain environment with service contract. Eur. J. Oper. Res. 2015, 244, 792-802. [CrossRef]

63. Norwegian Ministry of Trade, Industry and Fisheries and Norwegian Ministry of Petroleum and Energy. New Growth, Proud History. The Norwegian Government's Ocean Strategy; Norwegian Ministry of Trade, Industry and Fisheries and Norwegian Ministry of Petroleum and Energy: Oslo, Norway, 2015; p. 105.

64. Wang, S.; Notteboom, T. The role of port authorities in the development of LNG bunkering facilities in North European ports. WMU J. Marit. Aff. 2015, 14, 61-92. [CrossRef]

65. North European Oil Trade. LNG as a Ship Fuel in the Baltic Sea Region: Study for LNG Supply Chain; NEOT: Helsinki, Finland, 2015; p. 40.

66. Rodrigues, A.P.R.D.S. The Training of Officers and Crew of LNG-Fuelled Vessels: A Case Study of Norway. Master's Thesis, Chalmers University of Technology, Göteborg, Sweden, 2013.

Publisher's Note: MDPI stays neutral with regard to jurisdictional claims in published maps and institutional affiliations.

(C) 2020 by the authors. Licensee MDPI, Basel, Switzerland. This article is an open access article distributed under the terms and conditions of the Creative Commons Attribution (CC BY) license (http://creativecommons.org/licenses/by/4.0/). 